\title{
Womanist Expressions in the Poetry of Judith Wright and Oodgeroo Noonuccal
}

\section{Dr. Bhavna Sharma}

Assistant Professor, Amity University, Haryana, India

\begin{abstract}
Judith Wright and Oodgeroo Noonuccal, two well-known poets of Australia, consider woman to be the moral fiber of society playing an integral role to build the other life-sustaining relationships. Woman, they assert is the real maker of a "family" and her soul is steeped in the values and ideology of the society. But the tragedy lies in the fact that she is devoid of the real happiness of life. The poetic works of both the poets reveal their profound sympathy for women and their struggle to realize their desires and ambitions, both inside and outside. Dealing with the disappointment, senselessness and torment of women in a patriarchal society they depict how patriarchal attitudes are bred through various socialization processes like family, marriage, religion and education. Their poetry deal with the roles played by women that placate their life with love and care revealing also the difficulty faced in search of finding their identity and individuality. The poets view love as an ideology and also as one of the primary means through which women are subordinated and suppressed to the extent of losing their identity. However, both the poets also salute the hidden strength in women capable of bringing revolution when the appropriate time comes. Their expressions reveal that women need to voice their suffering, break the chains of the patriarchal system and develop a new set of values to liberate them from male prejudice placing them on equal terms. Both the poets have cross-culturally tried to educate women to take a stand against their suppression and oppression and show their determination to resist further exploitation to ascertain human status.
\end{abstract}

Keywords— patriarchal system, women's identity, liberation, humanity.

The world of females, since the beginning have been an intriguing exploration for writers. There was a time when females and their sentiments were not addressed by the traditional society as she was not subjected to express freely her affections or dissatisfactions. It was in the late $18^{\text {th }}$ and $19^{\text {th }}$ century that women began to show interest towards writing as a reliable source to express their sensibility. However, they preferred to use pseudonyms or remain anonymous in that scenario. Feminism and Women's Liberation Movement greatly supported the reformation of women eliminating the forms of tyranny based on gender and with the efforts sensibility as a concept emerged in $18^{\text {th }}$ Century Britain. The term describes people's capacity to be affected by the world around them and correlating emotional capabilities with moral development. Feminine sensibility means sentiments of a woman concerned with feelings and emotions to her circumstances. It refers to the emotions stored in the heart having a capacity to overwhelm the surroundings. Feminine sensibility has been a major concern for writers as they have been deeply sympathetic with the struggle of females, both inside as well as outside and in the efforts have realistically portrayed the world of females expressing their expectations, conflicts, torments, struggle and above all their individuality. Judith Wright and Oodgeroo Noonuccal, the two most well-known poets of Australia, deal with such a world that reveals the life of woman with her relationships that placate her with love and care. They also focus on the journey of a woman in search of her identity and individuality.

Judith Wright and Oodgerro Noonuccal assert that woman is the real maker of a "family" and her soul is steeped in the values and ideology of the society. They consider woman to be the moral fiber of any society playing an integral role to build the other life-sustaining relationships. They believe the strongest of emotions, that is, love transforms her life. Judith Wright considers love as a potent force that thrusts and 
builds up the inner positive strength and imparts courage to face the intricacies of life "Only those men survive/ who dare to hold their love against the world" $(\mathrm{CP}, 45)$. She describes love as a strong reciprocal sentiment which cancels fear "since love, who cancels fear/ with his fixed will,/ burned my vision clear/ and bid my sense be still" $(\mathrm{CP}, 30)$. Judith describes the feeling and expression of love as follows:

Love, from its unknown centre,

spins a silence like thought;

and deep there as the heart can enter

my wholeness I sought.

(CP, 151).

According to Oodgeroo Noonuccal love is a feeling that knows no partiality. She places it at the highest pedestal because it is "love that sustains us" (MP,99) and it binds two souls, family, community and the entire humanity. Like Sufi Saints love is a pure and mystic feeling for her. It is a gift given by God as God "who made us all, and all His children $\mathrm{He} /$ Loves equally" (MP,47). But the earthly existence has added another characteristic to such a chaste emotion that it has become "lost, neglected love" (MP,80). In the poem Kiltara-Biljara (Eagle-Hawk) Noonuccal talks of the hurt and pain associated with love: "Love hurts too much/ And you are battle-scarred/ From too many rejected loves." (MP,101) Love, Noonuccal feels is a mixed bag which "bring(s) life sweetness" but one should also be ready to "Welcome too its pain" (MP,73). Love does not come alone but is accompanied by its "companion Sorrow" (MP,73). In the poem Song she conveys her outline of love:

Life is ours in vain

Lacking love, which never

Counts the loss or gain.

But remember, ever

Love is linked with pain.

(MP,73)

Both the poets acknowledge the power of love that shapes the life of a woman. For them the concept of love and life force are inextricably intertwined since they believe that "life is the basis of truth and for life love is the dynamic principle." [Inglis,77] However, they also acknowledge the disappointment, senselessness and torment associated with this feeling. They assert that the patriarchal attitude has created a huge culture between men and women through various socialization processes such as family, marriage, religion and education. Judith Wright conveys that women is the one who gives "breath and life" to others and takes into herself "all living things that are" $(\mathrm{CP}, 30)$ but her position lies desolate making her question "Then why is my blood not quiet? What is the good/ of the whips of music stinging along my blood?" (CP,64) The Forest Path pictures the journey of a woman who regrets the "loss of self" and "the darkness" which she faces in her life: downwards-

When the path we followed began to tend how it came about we hardly now rememberwe followed still, but we did not expect this, the loss of self, the darkness and the forest. $(\mathrm{CP}, 111)$

Similar grief is movingly expressed in Half-Caste Girl where the girl is trapped and assimilated into the patriarchal society:

She used her love for lever;

but the wall is cunningly made.

Not even the strong break jail.

So she is restless still under her rootwarm cover,

hearing the noise of living,

forgetting the pain of dying.

$(\mathrm{CP}, 19)$

Oodgeroo Noonuccal depicts the appalling situation of women which leads to their loss of identity. In her poem Namatjira she exclaims with dread about the position provided to women: "What did their loud acclaim avail/ Who gave you honour, then gave you jail?" (MP,61) Noonuccal successfully portrays the dissatisfaction and psychological traumas faced by woman. Her anger is projected to see the struggling life of females, "Women working from dawn to dark, trapped and unhappy;" (MP,27) and "were forced and assailed,/ For fighting degradation they were bashed and jailed" (MP,85). Her poetry deals with the darkness inside a woman's heart "Though baptised and blessed and Bibled/ We are still tabooed." (MP,87) In the poem The Child Wife she reveals how the laws and norms of the society trap the life of a girl and show no concern to her feelings. Her life becomes meaningless when she is handed over to an "old man". The torments of emotions inside her heart are described as:

"It was love I longed for,

Oh, old laws that tether me! 
Oh, long years awaiting me!

And the grief comes over me,

And the tears fall down.

(MP, 12)

Wright and Noonuccal acknowledge the words of D.H. Lawrence who has rightly pointed out that "The great relationship for humanity will always be the relationship between man and woman. The relationship between man and man, woman and woman, parent and child will always be subsidiary" [Lawrence, 130]. In the poetry of Judith Wright, the earthly love is linked with eroticism and titillation. It emerges as a cardinal desire whereas Noonuccal dismisses this romantic idealism. She views it as a pragmatic relationship where man offers sustenance to woman. In the poetic world of Wright, females are expressive, open and demanding in love whereas in case of Noonuccal they are submissive, compliant and docile. Referring to Wright's poems of Woman to Man, Brady exclaims that these are not just poems about 'women's experience' rather they are attempts at the 'felt change of consciousness' [Brady,136137]. Both the poets reveal that woman invest more in love and give more affection than they receive. The fact is that women prefer to be more connected while men prefer to be more autonomous and withdrawn. Even when they try to reinforce intimacy, their efforts often result in a failure of intimacy. They agree with Tannen who writes: "Trying to trigger a symmetrical communication, they end up in an asymmetrical one" (Tennen,190). However, they both salute the hidden strength in the soul of women who exhibit it when the appropriate time comes. They both salute this quality of woman who is capable of bringing revolution. Judith Wright in her poetry portrays the tremendous fight woman puts in the course of life. She is instilled with certain virtues which mark her spirit and lend her endurance and perseverance. Her patience plays a commendable role but her sense of justice is extremely strong to put an end to her sufferings and torment that she is subjected to. For her potency and inner strength she is admired as in the poem Waiting Ward where "some wore fear like a wound" or "hope like a flower" or "waited for the touch of joy" or "summons of terror" but the girl who "wore fear like a flower" is remembered and admired:

But I would have her remembered,

the girl with the red hair.

She wore fear like a flower

and carried death like a child. she was the ace of spades,

she knew the future early-

the girl who sang and smiled

and carried a black secret.

$(\mathrm{CP}, 104)$

In the poem Forever she makes a universal appeal: No one can live there always,/ the frost-bound queen of Never./ Once the blood moves, the flood moves." (CP,312) Noonuccal also personifies the hidden strength of women. In her poem Daisy Bindi she upholds the strength of character a woman possesses. Her persistence in achieving her goal is a quality that the protagonist Daisy Bindi exhibits in order to fight against the evil slavery. She "rode like a man" "where aid there was none" and "organised her clan/ To strike for native justice and the plan rights of man". She succeeds in her mission and "championed her people out of servitude". Oodgeroo "Salutes to a spirit fine" who "dared to challenge slavery":

\section{High praise and honour to \\ Daisy of the Noongahs who \\ Fought and routed tyranny, \\ Dared to challenge slavery.}

$(\mathrm{MP}, 85)$

In the poem The Teacher Noonuccal also makes a universal appeal to the world to educate women as culture imprisons them since the majority of them have accepted the status quo to the extent that they worship male domination: 'No more gammon,/ If you have to teach the light,/ Teach us first to read and write.'(MP,23) Judith Wright and Oodgeroo Noonuccal have cross-culturally represented the state of women and have depicted how patriarchal intrusion exists in both the cultures. Discussing the problem of identity, they express the following words: "Women have not learned to see themselves because the mirrors they look into do not reflect them. They reflect the male idea of a woman- whether married or single."[Jain,51] Both the poets have crossculturally tried to educate women to take a stand against their suppression and oppression as they both consider that without the urge to see herself as an individual no woman can really think of marching ahead to ascertain a human status for herself. Women need to take a stand for themselves, voice their sufferings and show their determination to resist further exploitation. They need to break their chains of the patriarchal system, develop a new

ISSN : 2456-7620 
set of values which liberates them from male prejudice and places them on equal terms.

\section{REFERENCES}

[1] Brady, Veronica. South of My Days: A Bibliography of Judith Wright. Sydney: Harper Collins. 1998.

[2] D.H. Lawrence, "Morality and the Novel", in David Lodge ed. $20^{\text {th }}$ Century Literature Criticism. London: Longman 1972.

[3] Jain, Jasbir. "Gender and Narrative Strategy" in Gender and Literature. ed. Iqbal Kaur

[4] Moore, Inglis. 1968. On Native Grounds. Sydney: Angus \& Robertson.

[5] Noonuccal, Oodgeroo. My People. Queensland: The Jacaranda Press, 1990. (Quoted as MP)

[6] Tannen, Deborah. "You Just Don't Understand." in Estelle Disch (ed.). Reconstructing Gender: A Multicultural Anthology. Toronto: Mayfield Publishing Company. 1997.

[7] Wright, Judith. Collected Poems 1942-1985. Sydney: Angus \& Robertson, 1994. (Quoted as CP) 